\title{
PHONETIC GRAMMAR OF PLOSIVES SOUNDS SPOKEN BY SUNDANESE AND JAVANESE
}

\section{GRAMATIKA FONETIK BUNYI PLOSIF YANG DIUCAPKAN OLEH PENUTUR SUNDA DAN JAWA}

\author{
Yusup Irawan, ${ }^{\mathrm{a}}$ Riani $^{\mathrm{b}}$ \\ Balai Bahasa Provinsi Jawa Barata \\ Jalan Sumbawa 11, Bandung, Indonesia \\ Balai Bahasa Provinsi Daerah Istimewa Yogyakartab \\ Jalan I Dewa Nyoman Oka 34, Daerah Istimewa Yogyakarta, Indonesia \\ haiyusupirawan@gmail.com; riani@kemdikbud.go.id
}

(Naskah diterima tanggal 12 Maret 2021, direvisi terakhir tanggal 31 Mei 2021, dan disetujui tanggal 25 Juni 2021)

DOI: https:/ / doi.org/10.26499/wdprw.v49i1.802

\begin{abstract}
Abstrak
Penelitian ini bertujuan untuk mengidentifikasi gramatika fonetik "phonetic grammar" bunyi-bunyi letupan bersuara $[b, d$, dan $g]$ dan tak bersuara $[p, t$, dan $k]$ pada posisi awal kata yang diucapkan oleh dua kelompok penutur jati yang berbeda: Sunda dan Jawa. Bunyi-bunyi itu secara fonemik merupakan fonem yang sama dalam bahasa Sunda, Jawa, dan Indonesia. Temuan dalam penelitian ini adalah kedua kelompok penutur jati merealisasikan pola VOT (voice onset time) bunyi letupan yang berbeda dan sama. Untuk bunyi-bunyi bersuara plosive lenis $[\mathrm{b}, \mathrm{d}$, dan $\mathrm{g}]$ penutur bahasa Sunda merealisasikannya dengan pola VOT negatif, sedangkan penutur bahasa Jawa merealisasikannya dengan pola VOT positif. Kemudian bunyi-bunyi letupan bersuara yang diucapkan oleh penutur bahasa Jawa cenderung "beraspirasi" atau breathy. Pada bunyi-bunyi takbersuara atau plosive fortis [p, $t$, dan $\mathrm{k}]$, kedua kelompok penutur mengucapkannya dengan pola yang sama, yakni pola VOT positif bahkan cenderung ber-VOT nol atau zero. Pola-pola VOT itu merefleksikan kategori fonasi bersuara breathy dan takbesuara untuk bahasa Jawa dan bersuara dan tak bersuara untuk bahasa Sunda.
\end{abstract}

Kata-kata Kunci: vot (voice onset time); bunyi letupan; Sunda; Jawa

\begin{abstract}
This study aims to identify "the phonetic grammar" of voiced plosive sounds $[b, d$, and $g]$ and voiceless $[p, t$, and $k]$ at the initial position of the words uttered by two different groups of native speakers: Sundanese and Java. These sounds are phonemically the same phonemes in Sundanese, Javanese and Indonesian. The findings show that the two groups of native speakers realize different and the same VOT (Voice Onset Time) pattern of popping sounds. For sounds voiced plosives or lenis plosive $[b, d$, and $g]$, Sundanese speakers realize it with a negative VOT pattern, while Javanese speakers do it with a positive VOT pattern. Then, voiced plosive sounds uttered by Javanese speakers tend to be "aspirated" or breathy. For the voiceless plosives or fortis plosives $[p, t$, and $k]$, the two groups of speakers pronounce them in the same pattern, namely the positive VOT pattern, and even tend to have zero VOT. The VOT patterns reflect aspirated voiced and voiceless phonation categories for Javanese and voiced and voiceless for Sundanese.
\end{abstract}

Keywords: VOT (voice onset time); pop sound; Sundanese; Javanese 


\section{Introduction}

The study of language sounds can be divided into two levels: the abstract level or phonemic level and the physical level or phonetic level. In Indonesia, in general, the study of language sounds can be said to still focus on the level of the language sound system or phonemic. Generally, these studies revolve around the topic of inventorying phonemes and comparing phonological systems, for example, the studies conducted by Sanjoko (2015), Swandana (2018), and Erniati (2020). These studies have not examined further the phonetic characteristics of the inventoried phonemes. One example of a study of language sounds at the phonetic level that has succeeded in describing the phoneme of plosive sounds is what was done by $\mathrm{Li}$, Baryadi, and Wijana (2019) to the Indonesian plosive sounds. Besides explaining the existence of the language plosives sounds, the research described the acoustic patterns of the sounds phonetically.

Generally, linguists know (1) where the plosive sounds are articulated in our oral cavity, (2) how they are articulated, and (3) whether the burst of the consonants are articulated with the closed vocal fold (voiced) or open vocal fold (voiceless). For example, the sounds [p] and [b] as in the words [pipi] 'cheek' and [bibi] 'aunt' are plosives bilabial consonants because the sounds are articulated by blocking the flow of air in the oral cavity with two lips: the upper lip and the lower lip, causing an air pressure. Then, the air pressure is released suddenly by opening the lips.
Theoretically, one of the ways to describe the characteristics of plosive sounds is by identifying the voice onset time (VOT) of the plosives sounds. VOT can be defined as the time interval between the release of a consonant sound and the voicing of a vowel sound (Sukmawijaya, Mahdi, and Yuliawati, 2020). The research results of Lisker and Abramson (Lisker and Abramson, 1964) stated that VOT is the most effective measure for classifying plosive consonant sounds into several phonetic categories in many languages: the sound perceived as a voice plosive consonants or perceived as voiceless plosive consonants. Furthermore, they said that, in fact, VOT can be a distinguishing feature between one language and another. After conducting a study of the results of VOT research in the past 50 years Cho et al. (2019) conclude that VOT functions as a first estimate of voicing contrast. In this case, the languages of the world can be categorized into (1) Languages with twoway contrast, (2) Languages with three-way contrast, (3) Languages with more than a three-way contrast: four-way and five-way contrast. They also said that Universal feature systems (of languages) are reflected in VOT and VOT functions as a controllable metric and the phonetic grammar (Cho, Whalen, and Docherty, 2019).

In Navajo language, the voiceless plosive consonant sound [th] in [tha] has a positive VOT with a longer time interval than the positive VOT sound [t] in [ta]. In Navajo, the sound [th] has a positive VOT with a longer time interval than a positive VOT of the same sound in Sindhi. According to Ladefoged (Ladefoged, 2003), 
VOT [th] in Navajo is 150 milliseconds, whereas in Sindhi it is only 75 milliseconds.

A plosive sound is categorized as a positive VOT if the release of consonant energy precedes the onset of vocal cord vibration (voicing). A plosive sound is categorized as a negative VOT if the vibration of the vocal cords (voicing) precedes the release of consonant sound energy and a VOT zero occurs if the plosive release "coincides" with the vibration of the vocal cords (Ladefoged \& Johnson, 2011). A plosive sound can be categorized into long lag VOT, short lag VOT, and prevoicing. Long VOT lag occurs when the interval between releasing and voicing is more than 35 milliseconds (msec). A plosive sound is categorized as short lag if the VOT value is less than 30 milliseconds (Kent \& Read 2002). A plosive sound is categorized as prevoicing if the vibration of the vocal cords occurs before the release of the plosive sound and is usually called a negative VOT.

Ladefoged and Johnson (Ladefoged and Johnson 2011) gave an example of the differences of VOT plosive sounds in a language or between languages. The Sindhi language, we can see the relative difference in VOT between [da], [ta], and [tha]. Those VOT of the plosive sounds were measured in milliseconds (ms). The plosive consonant [d] in [da] is characterized by a negative $V O T$ because the vibrations of the vocal cords or voicing begin to occur before the release of air pressure relative to the 0 millisecond time point, while the burst consonant [t] in [ta] is characterized by a positive VOT due to vocal fold vibration occurs after a release of air pressure relative to a point in time of 0 milliseconds.
Figure 1. VOT of plosive sounds in Sindhi and Navajo language (Ladefoged and Johnson 2011)

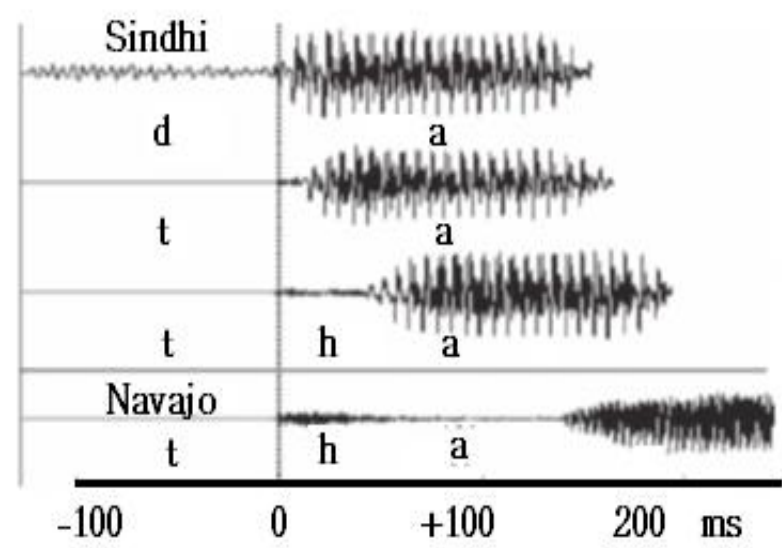

In sum, the theory used in this study is the classification of the VOT plosive sounds based on three categories, namely positive VOT, negative VOT, and zero VOT (Hussain 2018; Li et al. 2019; Lisker and Abramson 1964; Nakai and Scobbie 2016; Ünal-Logacev, Fuchs, and Lancia 2018). A plosive sound is classified as positive VOT if the burst of a consonant sound precedes the onset of voicing. If the onset sound begins before the outburst of a consonant, the plosive sound is categorized as having a negative VOT. If the burst of a consonant sound coincides with the onset of the sound, the sound is categorized as VOT zero. With regard to the laryngeal category, the plosive sounds to be studied will be classified into voice, voice aspirated (breathy), voiceless, voiceless aspirated, and voice implosive (Cho et al. 2019) (Solé 2018).

This study aims to identify the "phonetic grammar" of the plosive sounds as the same phonemes in Sundanese, Javanese, and Indonesian languages spoken 
by two different ethnic speakers: Sundanese and Javanese.

This research is useful for knowing the similarities and differences between plosives sound patterns in Sundanese and Javanese as the same phoneme but may have different phonetic grammar. This study is also useful to know the diversity of pronunciation of plosive sounds in Indonesian by speakers of different languages: Sundanese and Javanese.

\section{Method}

The data of research collected are oral data obtained through recording. The research data were collected using the following procedure. First, the researcher made a data collection instrument in the form of a vocabulary list containing voiced plosive sounds/lenis: [b], [d], [g] and voiceless plosive sounds/fortis: $[\mathrm{p}],[\mathrm{t}],[\mathrm{k}]$ at the beginning of the word. These sounds exist in the Javanese, Sundanese, and Indonesian language systems (Satjadibrata, 2011) and (Tiani, 2015).

The target words containing plosive sound are words that also exist in Javanese, Sundanese and Indonesian, namely [baris] 'line', [babat] 'tripe', [dalang] 'master puppet', [dapur] 'kitchen', [gabah] 'paddy grain', [gagal] 'fail', [pasar] 'market', [payung] 'umbrella', [tali] 'string' and [tahu] 'tofu'. The target of pronunciation words are words with the CVCVC and CVCVC structures. The first syllable consists of voiced plosive consonants and voiceless plosives followed by a vowel sound [a].

The same word selection strategy was chosen in the two languages to see more clearly the phonetic differences of plosive sounds which were realized by informants with different language backgrounds: Javanese and Sundanese. The researcher also did not collect data in the form of recorded sentences or naturally spoken speech to facilitate the analysis of plosive sounds. Based on the data collection test and analysis, the plosive sounds that are inserted in the sentence overlap with other sounds or are called coarticulation (Mildner, 2018).

To obtain oral data, the informants ( 2 men and 2 women with Javanese and Sundanese language backgrounds, a total of 8 informants) were asked to read a vocabulary list. The informant's age were between 20-25 years old. Most of them were students. The list had been randomized repeatedly and inserted with other words that were not the target words. A total of 288 pronunciations of words containing voiced and unvoiced plosives were produced.

Furthermore, the data were analyzed with a speech analyzer device, namely PRAAT. PRAAT was used to see the characteristics of the plosive sound pronounced by speakers of Javanese and Sundanese with the VOT theoretical framework. The analysis began with spectrographic analysis assisted by visual analysis of the waveform. To obtain maximum results, the researchers used a broadband spectrogram setting: window length 0.005$)$, a frequency range of $0-8000 \mathrm{~Hz}$, and a dynamic range of 60 decibels.

\section{Figure 2. Identification of VOT Plosive Sound and Its Measurement}

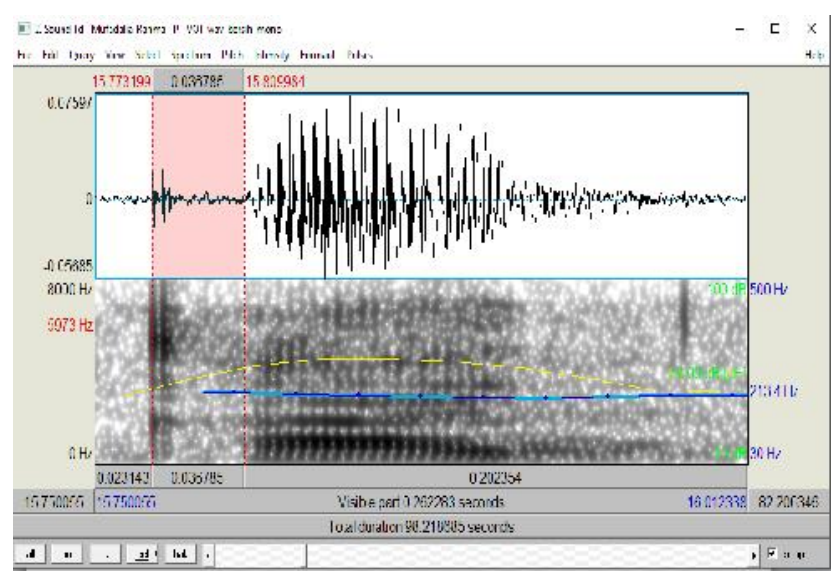


Through the Sound Editor PRAAT window, the researchers identified the VOT pattern of plosive sounds uttered by speakers. Theoretically, three possible VOT sound patterns were identified: positive VOT, negative VOT, and zero VOT. After identifying the VOT pattern, the next step was to measure the release burst to the onset of the vowel sound (first periodic cycle of the vowel) as shown in Figure 2.

\section{Result and Discussion}

This section discusses the research findings. In general, it can be explained that there are differences in the phonetic realization of plosive sounds spoken by native Sundanese speakers with the phonetic realization of plosive sounds uttered by native Javanese speakers. The analysis of plosive sounds is carried out visually: spectrographic analysis and acoustic measurement: as depicted in Figure 2.

We found there are differences and similarities in the phonetic characteristics of the plosive sounds uttered by Javanese and Sundanese speakers. The most striking difference between the two groups of speakers from different first language backgrounds is the plosive sounds [b], [d], [g]. Javanese speakers characterize voiced plosive sounds with positive VOT, while Sundanese speakers characterize voiced plosive sounds with negative VOT. Both Javanese and Sundanese speakers characterize voiceless plosive consonants [p], [t], and [k] with the same VOT pattern, namely positive VOT.

In general, voiced plosive sounds are relatively easier to observe visually than voiceless plosive sounds because voiced plosive sounds tend to have greater energy than voiceless plosive sounds. Voiced plosive sounds with a positive value, in this research, uttered by Javanese speakers tend to be easier to measure than voiceless plosive sounds because the duration of the VOT is relatively long. In sum, the finding can be formulated by $[b, d, g]>[p, t, k]$ in terms of the energy and duration of the VOT as portrayed in the following illustration.

\section{Figure 3: The VOT data of Sundanese and Javanese}

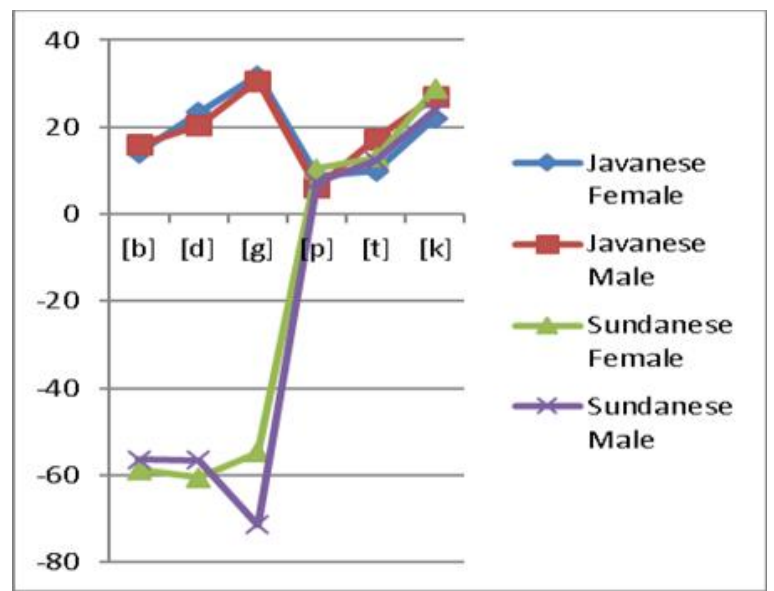

The location of the articulation seems to affect the amount of energy burst and its acoustic value. The burst of plosive sounds pronounced in the front area/anterior area, such as bilabial plosive, tends to be more difficult to observe and measure because the energy of spike is less and the duration from release to onset voicing is shorter than the release of plosive sounds in the oral cavity area. The deeper the articulation lies, the easier the VOT of the plosive sounds to observe and measure. On contrary, the farther the articulation lies, the VOT of the plosive sounds is more difficult to measure and to observe.

Thus, it can be said that the VOT plosive sound [g], the plosive velar sound, is the plosive sound. It is the easiest to be observed and measured, while the VOT plosive sound [p], the bilabial plosive sound, is the most difficult to observe and measure the plosive sound. It can be formulated that $[\mathrm{g}]>\{\mathrm{d}]>[\mathrm{b}]$ and $[\mathrm{k}]>[\mathrm{t}]>[\mathrm{p}]$. 
The measurement results show that the mean VOT values for the plosive sounds [b], [d], and [g] spoken by Javanese females and males are 22 and 23 milliseconds. The value is not far apart, while Sundanese females realized VOT for the voiced plosive group in the range of 57 milliseconds and Sundanese males realized it in the range of -61 milliseconds. These numbers indicate that Sundanese speakers characterize a voiced plosive sound by vibrating the vocal cords before releasing their plosive sound energy, while Javanese speakers realized voiced plosive sound by releasing sound energy and followed by vibrations of the vocal cords (voicing).

On the other hand, the measurement results show that the average VOT value of the plosive sounds [p], [t], and [k] spoken by Javanese females and males is the same, which is 13 milliseconds. Meanwhile, the average VOT value of Sundanese females is 17 milliseconds and Sundanese male's VOT average is 14 milliseconds.

\subsection{Plosives Sounds Spoken by Sundanese}

There are differences in voiced plosive sound patterns with voiceless plosive sounds uttered by Sundanese informants. However, it seems that gender differences do not affect their VOT patterns. Thus, there is no difference in the pattern of plosive sounds uttered by male and female informants. Therefore, the two groups of speakers are the same when realizing the VOT pattern of plosive sounds, both voiced plosive, and voiceless plosive sounds.

As previously explained, the plosive sounds [b], [d], and [g] spoken by Sundanese speakers are characterized by a negative VOT pattern. On average, female Sundanese pronounced voice plosive sounds [b], [d ], and [g] in the range $-58,-60$, and -54 milliseconds (VOT), while male Sundanese pronounced the sounds in the range $-56,-56$, and -71 milliseconds (-VOT).
Table 1

The VOT Value of Voice Plosive Sounds in Milliseconds

\begin{tabular}{|c|c|c|c|c|}
\hline Syllable & $\begin{array}{l}\text { Javanese } \\
\text { Female }\end{array}$ & $\begin{array}{l}\text { Javanese } \\
\text { Male }\end{array}$ & $\begin{array}{l}\text { Sundanese } \\
\text { Female }\end{array}$ & $\begin{array}{l}\text { Sundanese } \\
\text { Male }\end{array}$ \\
\hline [b] & 14 & 15 & -58 & -56 \\
\hline [d] & 23 & 20 & -60 & -56 \\
\hline [g] & 31 & 30 & -54 & -71 \\
\hline Average & $\mathbf{2 3}$ & $\mathbf{2 2}$ & $\mathbf{- 5 7}$ & $\mathbf{- 6 1}$ \\
\hline
\end{tabular}

Table 2

The VOT Value of Unvoiced Plosive Sounds in Milliseconds

\begin{tabular}{|c|c|c|c|c|}
\hline Syllable & $\begin{array}{c}\text { Javanese } \\
\text { Female }\end{array}$ & $\begin{array}{c}\text { Javanese } \\
\text { Male }\end{array}$ & $\begin{array}{c}\text { Sundanese } \\
\text { Female }\end{array}$ & $\begin{array}{c}\text { Sundanese } \\
\text { Male }\end{array}$ \\
\hline$[\mathbf{p}]$ & 8 & 6 & 10 & 7 \\
\hline$[\mathbf{t}]$ & 9 & 17 & 13 & 12 \\
\hline$[\mathbf{k}]$ & 22 & 26 & 28 & 23 \\
\hline Average & $\mathbf{1 3}$ & $\mathbf{1 3}$ & $\mathbf{1 7}$ & $\mathbf{1 4}$ \\
\hline
\end{tabular}

Figure 4: Realization of The Plosive Sound [d] in The Syllable [da] in The Word [dalan 'master puppet' Pronounced by Female Sundanese

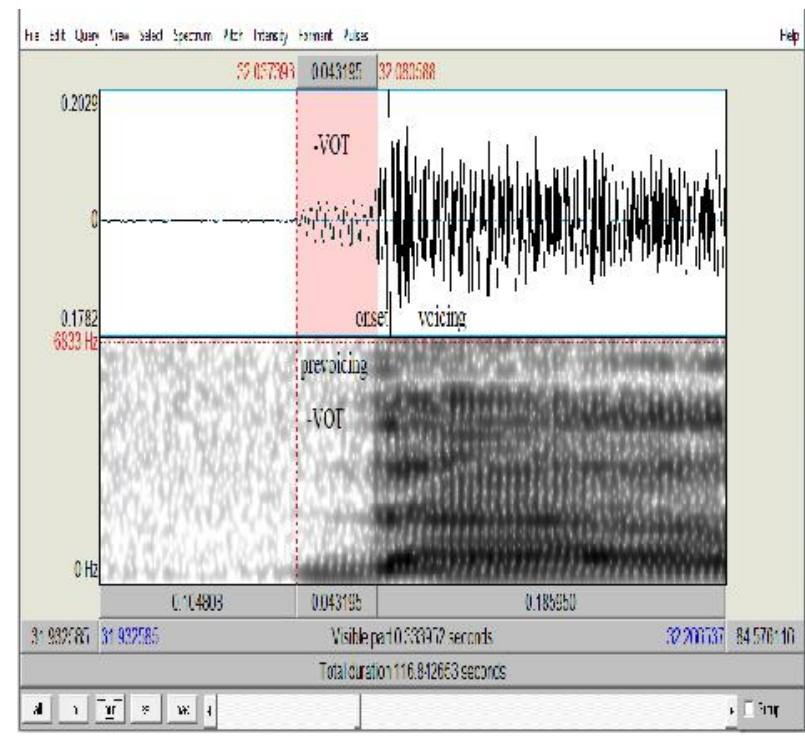

Figure 4 shows an example of the realization of plosive sounds uttered by Sundanese native speakers. The sound [d] in the syllable [da] in the word [dala ] 'master puppet' which is pronounced by a female Sundanese speaker is characterized by a negative VOT because the release of sound energy is preceded by the 
vibration of the vocal cords. The VOT value is identified from the regular sound wave pattern at the beginning of the sound in the waveform and the appearance of the periodic wave energy at the bottom of the spectrogram. Voice plosive sounds uttered by Sundanese speakers tend not to be "aspirated" unlike spoken by Javanese. This finding indicates that the phonation of the vocal cords is tightly closed so that voice plosive sounds uttered by Sundanese speakers are categorized as non-aspirate plosive sounds.

On the other hand, especially for voice plosive sounds uttered by Sundanese speakers, it seems that the relation pattern cannot be formulated. This finding is different from the pattern of voice plosive sound relations in Javanese, namely the relation $[\mathrm{g}]>$ $[\mathrm{d}]>[\mathrm{b}]$ in terms of the burst of sound energy and its VOT value.

Figure 5: Realization of The Plosive Sound [p] in The Syllable [pa] in The Word [pajun] 'umbrella' which is Pronounced by Female Sundanese

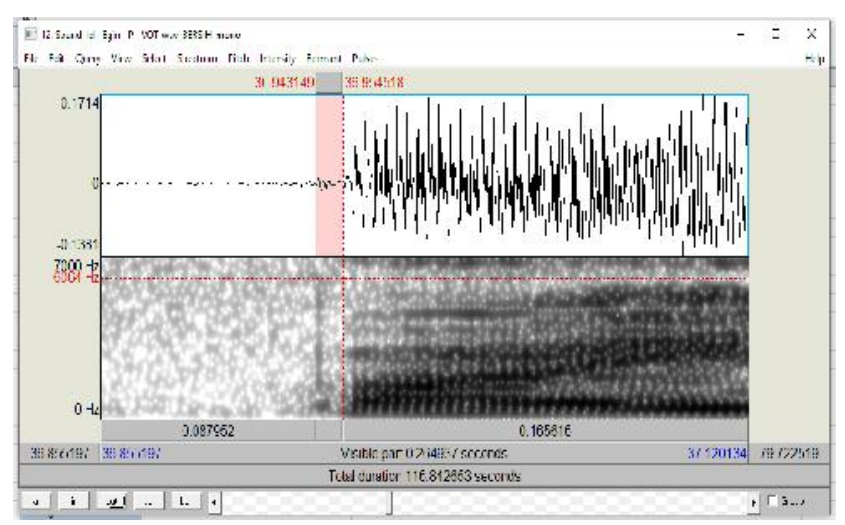

Figure 5 can represent the VOT pattern of voiceless plosive sounds uttered by Sundanese speakers. Unvoiced plosive sounds [p], [t], and [k] spoken by Sundanese speakers are characterized by a positive VOT pattern and are also not characterized by fractions indicating a category of the voiceless aspirated larynx as in voiceless plosive sounds in English (Shahidi and Aman, 2011; Sukmawijaya et al., 2020).

\subsection{Plosives Sounds Spoken by Javanese}

Plosive sounds, both voice plosive sounds ([b], [d], and [g]) and voiceless plosive sound uttered by native Javanese speakers have a positive VOT pattern. However, voice plosive sounds uttered by Javanese speakers tend to be confirmed so that the finding is an indication that voice plosive sounds in the language are categorized as voiced aspirated or breathy voiced. The sounds in this category are articulated with the phonation of the vocal cords which are not tightly closed.

Frications of plosive sounds uttered by Javanese speakers are characterized by irregular aperiodic sound waves and the waves are quite clearly observed in the waveform and spectrogram. The facts of frications in plosive sounds uttered by language speakers are most visible in velar plosive sound $[\mathrm{g}]$. The more back the plosive voiced articulated by Javanese speakers, the easier the sound is identified because of the strong sound energy and the relatively long duration of VOT. The frications of voice plosive sounds uttered by Javanese speakers can be seen in Figure 5.

Figure 5: Frications of The Plosive Sound [g] in The Syllable [ga] in The Word [gabah] 'paddy' Pronounced by Male Javanese

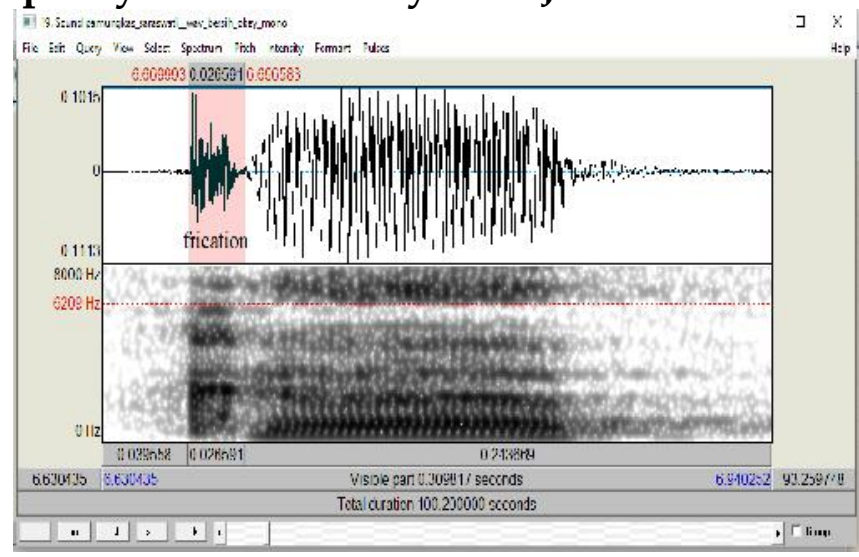


The peculiarity of Javanese speakers plosive sounds is familiar to Indonesian ears. Most Indonesians can easily guess the origin of a Javanese speaker with a hint of the peculiarity of its plosive sound that sounds louder than the plosive sounds of other local language speakers. The term usually attached to the voice plosive sound uttered by Javanese speakers is medhok (a heavily Javanese accent). The more medhok the articulation of Javanese speakers, the more it shows the strong influence of the Javanese language.

\section{Conclusions}

The research finds out VOT patterns of plosive sounds spoken by Javanese and Sundanese speakers. Phonetically, the two sounds have similarities and differences in patterns or characteristics. Voiced plosive [b], [d], and [g] spoken by Sundanese speakers have a negative VOT pattern. This finding indicates that Sundanese speakers when pronouncing a voiced plosive sound start with the vibrations of the vocal folds then followed with the release of the sound energy of the consonant. In this context, there is phonetic dissimilarity in phonemic similarity.

On the contrary, the Javanese speakers when pronouncing the plosive sounds [b], [d], [g] start by releasing consonant sound energy followed by vibrations of the vocal cords. Besides, Javanese speakers characterize voice plosive sounds with frication or aspiration so that the sounds are unique because they are generally different from voice plosive sounds spoken by other language speakers. The term often attached to the fact is "medok". The aspiration of plosive sound indicates the laryngeal category of voiced aspirated) or breathy voiced (Hussain 2018).

The finding also reveals that in the voiceless plosive sound group, the two groups of speakers: Javanese and Sundanese realize voice plosive sound with the same pattern. They both realize voiced plosives with a positive VOT pattern. Although Javanese speakers have voice aspirated sounds, this does not apply to voiced plosives. In this context, there is the phonetic similarity in phonemic similarity.

The findings in this study can illustrate the characteristics of plosive sounds in Sundanese and Javanese. With the assumption that there is interference from the first language (regional language) to the second language (Indonesian), this study illustrates that the VOT pattern of plosive sounds spoken by local language speakers will also affect Indonesian. In this case, the Javanese speakers will have difficulty eliminating the characteristics of the local language in the context of pronouncing plosive sounds in Indonesian.

\section{Bibliography}

Cho, Taehong, D. H. Whalen, and Gerard Docherty. 2019. "Voice Onset Time and beyond: Exploring Laryngeal Contrast in 19 Languages." Journal of Phonetics 72:52-65.

https:/ / doi.org/10.1016/j.wocn.2018.1 1.002

Erniati, NFN. 2020. "Sistem Fonologi Bahasa Melayu Dialek Ambon." BEBASAN Jurnal Ilmiah Kebahasaan dan Kesastraan 6(2):113. https://doi.org/10.26499/bebasan.v6i 2.116

Hussain, Qandeel. 2018. “A Typological Study of Voice Onset Time (VOT) in Indo-Iranian Languages." Journal of Phonetics 71(November):284-305. https:/ / doi.org/10.1016/j.wocn.2018.0 9.011

Ladefoged, Peter. 2003. Phonetic Data Analysis. Oxford: Blackwell Publishing. 
Ladefoged, Peter, and Keith Johnson. 2011. A Course in Phonetics. Sixth Edit. Michael Rosenberg.

Li, Huili, I. Praptomo Baryadi, and I. Dewa Putu Wijana. 2019. "Sound Pattern of Indonesian Plosives." Linguistik Indonesia 37(1):1-12. https://doi.org/10.26499/li.v37i1.84

Lisker, Leigh, and Arthur S. Abramson. 1964. "A Cross-Language Study of Voicing in Initial Stops: Acoustical Measurements." WORD 20(3):384-422. https:/ / doi.org/10.1080/00437956.196 4.11659830

Mildner, Vesna. 2018. "Aspects of Coarticulation." Challenges in Analysis and Processing of Spontaneous Speech (July):27-48.

Nakai, Satsuki, and James M. Scobbie. 2016. "The VOT Category Boundary in Word-Initial Stops: Counter-Evidence Against Rate Normalization in English Spontaneous Speech." Laboratory Phonology 7(1).

https://doi.org/10.5334/labphon.49

Sanjoko, Yohanis. 2015. "Perbandingan Karakteristik Fonem Bahasa Indonesia Dengan Bahasa Lasalimu." K Andai 11(1):55-67.

Satjadibrata, R. 2011. Kamus SundaIndonesia. Bandung: PT Kiblat Buku Utama.

Shahidi, A. H., and Rahim Aman. 2011. “An Acoustical Study of English Plosives in Word Initial Position Produced by Malays." 3L: Language, Linguistics, Literature 17(2):23-33.
Solé, Maria Josep. 2018. "Articulatory Adjustments in Initial Voiced Stops in Spanish, French and English." Journal of Phonetics 66:217-41.

https:// doi.org/10.1016/j.wocn.2017.1 0.002

Sukmawijaya, Jeri, Sutiono Mahdi, and Susi Yuliawati. 2020. “An Acoustic Analysis of Voiceless Alveolar Plosive / $t$ / in Sundanese, Indonesian, and English by Sundanese Speakers." Metahumaniora 10(1):1.

https:/ / doi.org/10.24198/metahuman iora.v10i1.26597

Swandana, I. Wayan. 2018. "Fonologi Bahasa Bali Dialek Jembrana." Jurnal Ilmu Sosial dan Humaniora 7(1):77-86.

Tiani, Riris. 2015. "Analisis Kontrastis Bahasa Jawa dengan Bahasa Indonesia." Humanika 21(1):1.

https:/ / doi.org/10.14710/humanika.2 1.1.1-6

Ünal-Logacev, Özlem, Susanne Fuchs, and Leonardo Lancia. 2018. “A Multimodal Approach to the Voicing Contrast in Turkish: Evidence from Simultaneous Measures of Acoustics, Intraoral Pressure and Tongue Palatal Contacts." Journal of Phonetics 71(November):395-409. https:/ / doi.org/10.1016/j.wocn.2018.1 0.002 